\title{
sciendo
}

DOI: 10.2478/fv-2020-0035

FOLIA VETERINARIA, 64, 4: 37-43, 2020

\section{EFFECTS OF LONG-TERM FEEDING OF TREATED RAPESEED MEAL ON GROWTH PERFORMANCE, BLOOD MINERAL PROFILE AND FATTY ACID COMPOSITION OF BACK FAT IN PIGS}

\author{
Bujňák, L. ${ }^{1}$, Nad', P. ${ }^{1}$, Skalická, M. ${ }^{1}$, Marcinčák, S. ${ }^{2}$ \\ ${ }^{1}$ Department of Animal Nutrition and Husbandry \\ ${ }^{2}$ Department of Food Hygiene, Technology and Safety \\ University of Veterinary Medicine and Pharmacy in Košice, Komenského 73, 04181 Košice \\ Slovakia \\ lukas.bujnak@uvlf.sk
}

\section{ABSTRACT}

This experiment was conducted to evaluate the effects of replacing soybean meal (SBM) with treated rapeseed meal (tRSM) on the growth performance, blood mineral levels and fatty acid composition of back fat in growing-finishing pigs. A total of 12 crossbred pigs (Slovakian White $\times$ Landrace) with an initial live weight of $40.82 \pm 2.69 \mathrm{~kg}$ were divided into two dietary treatments. The experimental period lasted 84 days; 38 days in the growing period and 46 days in the finishing period. The dietary treatments were as follows: control, a SBM-based diet (growing and finishing), and experimental, a treated RSM-based diet (growing and finishing). The rapeseed meal was treated with a product that neutralizes the negative physiological effects of anti-nutritive glucosinolates contained in rapeseed products for livestock feeding. Our analysis showed minor, no significant negative effects of tRSM on live weight, average daily gain and feed conversion ratio. Replacing SBM with tRSM had no significant effects on the proportion of the total saturated, monounsaturated and polyunsaturated fatty acids of back fat samples, as well as concentrations of analysed serum minerals except zinc level. In conclusion, the inclusion of $25 \%$ and $18 \%$ of treated RSM in growing and finishing pig diets had no negative effects on the growth performance, blood mineral profile or fatty acid composition of back fat.

Key words: growth performance; minerals; pigs; rapeseed meal

\section{INTRODUCTION}

Cereal/soybean meal-based diets are typical in pig farms located especially in countries where soybean meal is affordable [20]. Soybean meal (SBM) is the most widely fed protein source in pig diets [29] due to its content of highly digestible essential amino acids (lysine, but also threonine, tryptophan and isoleucine). SBM is characterised by high protein content (from 43 to $53 \%$ as fed) and low crude fibre content. But increasing dietary supplementation levels of SBM caused an increased feed cost in pig diets [12, 27] 
and also the potential health issues of genetically-modified (GM) soybean and other GM foods is a matter of considerable debate.

The worldwide increasing demand for proteins as animal feeding leads to a growing interest on other alternative protein sources for animals. Rapeseed is an alternative crop that can be grown in cold climates, and its cultivation has increased during recent years due to a growing demand for oil for biofuel production [14]. Rapeseed meal (RSM) is a by-product of rapeseed after the removal of its oil and is a cost effective protein source in pig diets and also an alternative ingredient to SBM [22]. Rapeseed meal generally contains $33 \%$ to $40 \%$ protein. The RSM has lower lysine but is richer in sulphur-containing amino acids (methionine + cysteine) compared to SBM [4]. It has been used in animal diets over an extended period of time, but due to a high fibre content, and anti-nutritional factors such as glucosinolates, tannins, and erucic acid, the inclusion of RSM in pig diets usually has been kept low [13]. Nevertheless, the beneficial effects of RSM dietary fibre on the intestinal health and overall well-being of pigs have been demonstrated [15]. The glucosinolates, anti-nutritional factors, have been demonstrated to impair growth and feed intake $[1,8]$. The anti-nutritional factors in rapeseed can be reduced by a number of techniques including physical, chemical, biological and crop breeding. But their efficacy varies from one treatment method to the other [17].

This fact motivated us to determine the effects of longterm feeding of treated rapeseed meal as the protein source in diets on growth performance, blood mineral profiles and fatty acid composition of the back fat in growing-finishing pigs.

\section{MATERIALS AND METHODS}

\section{Animals, diets and feeding}

A total of 12 crossbred pigs (Slovakian White $\times$ Landrace) with an average body weight (BW) of $40.82 \pm 2.69 \mathrm{~kg}$ were used for a 12 -week trial (84 days). Pigs were divided into two groups (6 pigs in each group). Both groups contained equal numbers of females (3) and castrated males (3).

The same basic ingredients for the control and the experimental groups were used in the study. The diets were formulated based on corn, wheat, barley, soybean meal or treated rapeseed meal, vitamin + mineral premix and synthetic amino acids. Dietary treatments were as follows: control, a SBM-based diet (growing and finishing) and experimental, a treated RSM-based diet (growing and finishing).

The rapeseed meal was treated with $2.5 \%$ LinaropAgri $^{\oplus}$ LRA (LINAGRI s.r.o., Czechia); the product that neutralizes the negative physiological effects of anti-nutritive glucosinolates contained in rapeseed and rapeseed products for livestock feeding. The nutritional characteristics of the treated RSM (97.5 \% rapeseed meal + $2.5 \%$ LRA) were the following: dry matter 897 g. $\mathrm{kg}^{-1}$, crude protein 349 g. $\mathrm{kg}^{-1}$, ether extract $16.1 \mathrm{~g} \cdot \mathrm{kg}^{-1}$, crude fibre $122 \mathrm{~g} \cdot \mathrm{kg}^{-1}$, neutral detergent fibre $197 \mathrm{~g} . \mathrm{kg}^{-1}$, calcium $6.1 \mathrm{~g} . \mathrm{kg}^{-1}$, phosphorus 1.08 g. $\mathrm{kg}^{-1}$, magnesium 4.6 g. $\mathrm{kg}^{-1}$, sodium 0.15 g. $\mathrm{kg}^{-1}$, potassium 1.05 g.kg-1, copper 8.9 mg. $\mathrm{kg}^{-1}$ and zinc 49.7 mg.kg-1 as feed basis. All diets met or exceeded the requirement of the National Research Council NRC [16]. The composition and analyses of diets are shown in Table 1.

All pigs were fed twice per day and the animals were given free access to water. Water was also provided directly in the trough during meals. Feed consumption and pigs' weight were recorded weekly to determine the average daily gain $(\mathrm{ADG})$, and feed conversion ratio (FCR). The investigation was carried out in the animal quarters of the Institute of Animal Nutrition and Dietetics at the University of Veterinary Medicine and Pharmacy in Košice in compliance with the EU regulations concerning the welfare of animals.

\section{Diets analysis}

The diets were analysed for their dry mater (DM), crude protein (CP), crude fibre (CF), neutral detergent fibre (NDF) and aether extract (EE) by the AOAC [2]. The starch content of the diets was determined using a fully automatic polarimeter. The feed samples were analysed for the presence of minerals (except phosphorus) using the flame method of an atomic absorption spectrometer. The determination of total dietary phosphorus was performed using the photometric method. The amino acids (AA) content in the diets were calculated according to the program for formulation of diets for pigs from the AA composition of feeds and the addition of synthetic amino acids. 
Table 1. Ingredients (\%) and chemical composition (g. $\mathrm{kg}^{-1}$, as feed basis) of diets for growing (G) and finishing (F) pigs

\begin{tabular}{|c|c|c|c|c|}
\hline \multirow{2}{*}{$\begin{array}{l}\text { Ingredients } \\
{[\%]}\end{array}$} & \multicolumn{2}{|c|}{ Control diet } & \multicolumn{2}{|c|}{ Experimental diet } \\
\hline & G & $\mathbf{F}$ & G & $\mathbf{F}$ \\
\hline Corn & 36.6 & 35 & 37.65 & 35 \\
\hline Wheat & 14 & 15 & 27 & 29.88 \\
\hline Barley & 28 & 34.35 & 7 & 14 \\
\hline SBM, CP $46 \%$ & 18 & 12.5 & & \\
\hline tRSM & & & 25 & 18 \\
\hline Premix VM & 3 & 3 & 3 & 3 \\
\hline Lysine & 0.20 & 0.08 & 0.24 & 0.09 \\
\hline Methionine & 0.08 & 0.03 & & \\
\hline Threonine & 0.12 & 0.04 & 0.11 & 0.03 \\
\hline \multicolumn{5}{|c|}{ Analysed content $\left[\mathrm{g} \cdot \mathrm{kg}^{-1}\right]$} \\
\hline DM & 896.7 & 891.7 & 891.5 & 894.8 \\
\hline $\mathrm{CP}$ & 160.5 & 140.8 & 161.2 & 141.3 \\
\hline EE & 28.8 & 23.3 & 30.8 & 25.1 \\
\hline $\mathrm{CF}$ & 25.6 & 35.2 & 27.9 & 42.5 \\
\hline NDF & 106.4 & 125.0 & 108.1 & 130.8 \\
\hline Starch & 466.3 & 488.9 & 460.9 & 478.2 \\
\hline $\mathrm{Ca}$ & 6.8 & 6.38 & 7.2 & 6.8 \\
\hline Total P & 5.4 & 5.0 & 5.3 & 4.7 \\
\hline \multicolumn{5}{|c|}{ Calculated content $\left[\mathrm{g} \cdot \mathrm{kg}^{-1}\right]$} \\
\hline Lys & 11.2 & 8.4 & 11.21 & 8.45 \\
\hline Thr & 7.25 & 5.6 & 7.3 & 5.6 \\
\hline Met + cys & 6.5 & 5.06 & 6.5 & 5.92 \\
\hline
\end{tabular}

SBM-soybean meal; tRSM —-treated rapeseed meal; DM—dry matter; $\mathrm{CP}$-crude protein; $\mathrm{EE}$-etheric extract; $\mathrm{CF}$-crude fibre; NDF-neutral detergent fibre; Lys-lysine; Thr-threonine; Met+cys-methionine+cysteine; $\mathrm{Ca}$-calcium; $\mathrm{P}$-phosphorus

\section{Blood mineral profiles}

Blood samples were collected from all pigs from the control and the experimental group and were obtained via the anterior vena cava at the end of the growing period (day 38). The concentrations of copper $(\mathrm{Cu})$, zinc $(\mathrm{Zn})$, calcium $(\mathrm{Ca})$, magnesium $(\mathrm{Mg})$, potassium $(\mathrm{K})$ and sodium $(\mathrm{Na})$ in the blood serum were determined using the flame method of an atomic absorption spectrometer (Unicam Solar 939, UK).

\section{Fatty acid composition of back fat}

The samples of the back fat from the 12 pigs were obtained at the end of the experiment (day 84). Samples for the determination of the fatty acid profiles were kept at $-20 \pm 2{ }^{\circ} \mathrm{C}$ for up to three weeks. The fatty acid composition of the back fat samples was determined by an evaluation of their methyl ester content via gas chromatography, according to Č e r tík et al. [7].

\section{Statistical methods}

All data were reported as the mean \pm SD (standard deviation). The differences between means were determined according to the unpaired t-test using the Graph-Pad Prism statistical program (Graph Prism software, USA). By conventional criteria, differences $(\mathrm{P}<0.05 ; \mathrm{P}<0.01$; $\mathrm{P}<0.001$ ) were considered to be statistically significant.

\section{RESULTS}

\section{Growth performance}

The live weights at the end the growing, the finishing and also the overall period were not significantly affected by the dietary inclusion of the treated RSM as an alternative to SBM. Although the animals from the experimental group achieved the higher final live weight at the end of the growing and finishing periods, there were no statistically significant differences between the experimental and the control group $(\mathrm{P}>0.05)$. The experimental period lasted 84 days; 38 days in the growing period and 46 days in the finishing period. During the growing, finishing and overall period, ADG was slightly lower in pigs fed the tRSM diet (experimental) than those fed the SBM diet (control), but there were no statistically significant differences in ADG between groups in the all periods $(\mathrm{P}>0.05)$. The feed conversion ratio (FCR) was a little poorer in pigs fed the tRSM diet in the growing $(-0.04 \mathrm{~kg}$ feed per $\mathrm{kg}$ gain) and in the overall period $(-0.03 \mathrm{~kg}$ feed per $\mathrm{kg}$ gain), whereas there were no differences in the FCR between groups in the finishing period (Table 2).

\section{Blood mineral profile}

The levels of selected mineral elements detected by atomic absorption spectrometry pointed to small changes in the amounts of mineral present in the blood serum (Table 3). On day 38 of the experiment, calcium (Ca), 
Table 2. Growth performance of growing-finishing pigs fed diets based on soybean meal (SBM) and treated rapeseed meal (tRSM) (means \pm SD)

\begin{tabular}{lcc}
\hline \multicolumn{1}{c}{ Diet } & $\begin{array}{c}\text { Control } \\
\text { (SBM) }\end{array}$ & $\begin{array}{c}\text { Experimental } \\
\text { (tRSM) }\end{array}$ \\
\hline Number of pigs & 6 & 6 \\
Live weight $[\mathrm{kg}]$ & & \\
Initial & $40.68 \pm 2.60$ & $40.95 \pm 2.78$ \\
End of the growing period & $76.25 \pm 5.58$ & $75.55 \pm 5.91$ \\
End of the finishing period & $114.9 \pm 8.15$ & $113.7 \pm 8.71$ \\
\hline \multicolumn{2}{c}{ Growing period } \\
\hline Days in the experiment & 38 \\
ADG [g] & $935.9 \pm 96.6$ & $910.5 \pm 103$ \\
FCR, kg feed per kg gain & 2.44 & 2.48 \\
\hline
\end{tabular}

\begin{tabular}{lcc}
\hline \multicolumn{3}{c}{ Finishing period } \\
\hline Days in the experiment & 46 \\
ADG $[\mathrm{g}]$ & $840.2 \pm 58.9$ & $829.7 \pm 69.3$ \\
FCR, kg feed per kg gain & 3.13 & 3.13 \\
\hline
\end{tabular}

\begin{tabular}{lcc}
\hline \multicolumn{3}{c}{ Overall period } \\
\hline Days in experiment & 84 \\
ADG $[\mathrm{g}]$ & $883.5 \pm 74.2$ & $866.3 \pm 83.3$ \\
FCR, kg feed per kg gain & 2.75 & 2.78 \\
\hline ADG - average daily gain; FCR-feed conversion ratio; SD—standard \\
\end{tabular}

magnesium $(\mathrm{Mg})$, sodium $(\mathrm{Na})$, potassium $(\mathrm{K})$ and copper $(\mathrm{Cu})$ levels were similar between two treatments $(\mathrm{P}>$ 0.05). The serum zinc levels were significantly higher ( $P$ $<0.05)$ in pigs fed the tRSM diet (experimental group) than those fed the SBM diet (control group). The detected amounts of calcium, magnesium, sodium and potassium in the blood serum of pigs from both groups were within the physiological range (Ca 2.4-3; $\mathrm{Mg} 0.5-1.3$; Na $140-$ 160; K 4-5 mmol. ${ }^{-1}$, respectively) [11]. The blood levels of $\mathrm{Cu}$ and $\mathrm{Zn}$ in both groups were also maintained within the normal physiological range ( $\mathrm{Cu} 20.4-47.2$ and $\mathrm{Zn}$ $10.7-22.9 \mu \mathrm{mol} . \mathrm{l}^{-1}$, respectively) [21].

\section{Fatty acid composition of back fat}

The results of the back fat fatty acid profile are shown in Table 4. The increase in $\alpha$-linolenic content in the back fat samples for the experimental group was significant $(\mathrm{P}<$
Table 3. Mineral profile of the blood serum samples (means \pm SD)

\begin{tabular}{|c|c|c|}
\hline Mineral & Control group & Experimental group \\
\hline Calcium [mmol.. $\left.{ }^{-1}\right]$ & $2.80 \pm 0.25$ & $2.67 \pm 0.10$ \\
\hline Magnesium [mmol. $\left.\mathrm{I}^{-1}\right]$ & $0.87 \pm 0.26$ & $0.79 \pm 0.08$ \\
\hline Sodium $\left[\mathrm{mmol} . \mathrm{I}^{-1}\right]$ & $159.90 \pm 2.91$ & $158.94 \pm 1.49$ \\
\hline Potassium [mmol. $\left.\mathrm{I}^{-1}\right]$ & $4.92 \pm 0.33$ & $4.72 \pm 0.32$ \\
\hline Copper $\left[\mu \mathrm{mol} . \mathrm{I}^{-1}\right]$ & $25.95 \pm 6.91$ & $22.38 \pm 4.87$ \\
\hline Zinc $\left[\mu \mathrm{mol} . \mathrm{I}^{-1}\right]$ & $17.35 \pm 2.03^{A}$ & $21.07 \pm 3.05^{B}$ \\
\hline
\end{tabular}

0.05). The proportion of palmitoleic acid in the back fat of the experimental group (tRSM diet) increased $(\mathrm{P}<0.01)$ compared to the control group (SBM diet). The proportion of total saturated FA, monounsaturated FA, polyunsaturated FA and also the proportion of other individual FA were not affected by the dietary inclusion of the treated RSM as protein feed in the diet of experimental group.

Table 4. Fatty acids profile $\left[\mathrm{g} .100 \mathrm{~g}^{-1}\right]$ of back fat samples (means \pm SD)

\begin{tabular}{lcc}
\hline \multicolumn{1}{c}{ FA } & $\begin{array}{c}\text { Control } \\
\text { group }\end{array}$ & $\begin{array}{c}\text { Experimental } \\
\text { group }\end{array}$ \\
\hline C14:0 (myristic) & $1.20 \pm 0.07$ & $1.15 \pm 0.06$ \\
C16:0 (palmitic) & $26.22 \pm 0.66$ & $25.74 \pm 0.33$ \\
C16:1 n-7 (palmitoleic) & $1.60 \pm 0.10 \mathrm{~A}$ & $2.10 \pm 0.30 \mathrm{C}$ \\
C18:0 (stearic) & $17.41 \pm 0.90$ & $16.80 \pm 1.08$ \\
C18:1n-9 (oleic) & $42.43 \pm 0.81$ & $43.29 \pm 0.95$ \\
C18:2n-6 (linoleic) & $6.46 \pm 0.44$ & $6.11 \pm 0.36$ \\
C18:3n-3 (a-linolenic) & $0.31 \pm 0.04 \mathrm{~A}$ & $0.37 \pm 0.03 \mathrm{~B}$ \\
C20:0 (arachidic) & $0.27 \pm 0.03$ & $0.28 \pm 0.03$ \\
C20:1 (eicosenoic) & $1.24 \pm 0.15$ & $1.19 \pm 0.12$ \\
C20:2 (eicosadienoic) & $0.39 \pm 0.05$ & $0.37 \pm 0.04$ \\
C20:3 (eicosatrienoic) & $0.02 \pm 0.01$ & $0.03 \pm 0.01$ \\
C20:4 (arachidonic) & $0.10 \pm 0.02$ & $0.12 \pm 0.01$ \\
SFA & $45.10 \pm 1.05$ & $43.97 \pm 1.10$ \\
MUFA & $45.28 \pm 1.01$ & $46.60 \pm 1.15$ \\
PUFA & $7.09 \pm 0.61$ & $7.00 \pm 0.42$ \\
\hline & & \\
\hline & &
\end{tabular}

FA - fatty acids; SFA — saturated fatty acids; MUFA - monounsaturated fatty acids; PUFA — polyunsaturated fatty acids; ${ }^{A, C}$ _ significant differences $(P<0.01) ; A, B$ - significant differences $(P<0.05)$; $S D$ — standard deviation 


\section{DISCUSSION}

A number of studies have shown that an increased use of RSM in pig diets holds a great potential to improve sustainability and self-sufficiency $[25,30]$. In our study, we reported the effects of a twelve-week dietary replacement of SBM with treated RSM on growth performance, blood mineral profiles and fatty acid composition of back fat in growing finishing Slovakian White $\mathrm{x}$ Landrace pigs. The rapeseed meal was treated with the product (intercalation complex), where the anti-nutritive compounds (e.g. glucosinolates) undergo a chemical conversion, the result of which is that the formed compounds are absorbed to a lesser degree and therefore may improve the digestibility of rapeseed meal.

Rapeseed meal, called canola meal (CM) in North America, Australia and some other countries, is the by-product of the extraction of oil from rapeseed. In several previous experiments, it has been demonstrated that between $15 \%$ and $30 \%$ of CM can be included in the diets fed to growing-finishing pigs without impairing their growth performance [10,23]. Growing-finishing pigs are expected to be more tolerant to the inclusion of high RSM levels than weanling pigs in terms of the effects on their growth performance [13].

In the results of the current study, live weight, ADG and FCR were not significantly affected by dietary inclusion of treated RSM in growing and finishing diets (25\% and $18 \%$, respectively). However, the effects of RSM or $\mathrm{CM}$ in pig diets has been reported to be inconsistent in many reports $[12,23,24]$.

The result of the $\mathrm{Ch}$ o i et al. [6] study indicated that RSM could be supplemented to growing-finishing diets up to $9 \%$ without detrimental effects on the growth performance of growing-finishing pigs. In that study, body weight, ADG, and gain/feed ratio were affected by dietary RSM supplementation levels up to $12 \%$.

$\mathrm{Yun}$ et al. [32] reported the inclusion of $4 \%$ of RSM or CM in finishing pig diets had no negative effects on the growth performance, nutrients digestibility, faecal noxious gas emission, blood characteristics, or meat quality.

A new study of S k u g o r et al. [26] was performed to investigate the effects of dietary inclusion of $20 \%$ rapeseed meal (RSM) as an alternative to soybean meal (SBM) in a three-month feeding experiment with growing finishing pigs. The dietary alteration affected the growth per- formance, and several carcass traits, but did not affect the measured meat quality traits.

The meta-analysis of $\mathrm{H}$ a n se $\mathrm{n}$ et al. [9] showed minor, but significantly negative effects of RSM on ADG and feed conversion, while regression analyses revealed no differences in the growth performance with increasing levels of RSM in the diets. Overall, the results suggested that low glucosinolate RSM can be used as an alternative feed resource without adverse effects on the growth performance if used in well-balanced diets for weanling and growing-finishing pigs [9].

The content of mineral elements in the protein sources does not meet the minimal nutritional requirements of pigs at the dietary levels of the protein supplements used in a balanced diet. It is usually met by adding a commercial trace mineral premix to the diet. Rapeseed meal is a better source of calcium, selenium and zinc than soybean meal, but a poorer source of potassium and copper. Its high phytic acid and fibre contents reduce the availability of many mineral elements [5]. In our study, blood mineral levels in both treatments were maintained within the normal physiological range. $\mathrm{Cu}$ and $\mathrm{Zn}$ are involved as co-factors in a myriad of metabolic enzyme systems within the pig [28].

The fatty acid profile of the pig back fat directly reflects the fatty acid profile of the pig diet [19]. Rapeseed oil is rich in MUFA and has higher levels of n-3 PUFA while soybean oil has a high C18:2 (linoleic) content and moderate levels of C18:1 (oleic) and C18:3 (linolenic acid). In pigs, dietary FAs are absorbed unchanged from the intestine and incorporated into tissue lipids [31]. Hence, dietary fat influences the FA profile of the adipose tissue [3]. Solvent-extracted rapeseed meal contains small amounts of residual oil (about $3 \%$ DM). In solvent-extracted soybean meals, the oil content is typically lower than $2 \%$. The dietary fat (ether extract) content in our diets varied between 23.3 and 30.8 g. $\mathrm{kg}^{\sim 1}$. In our study we did not observe any differences between the total proportion of saturated fatty acids (SFA), monounsaturated fatty acids (MUFA) and polyunsaturated fatty acids (PUFA) among the groups. There were a significantly higher level of monounsaturated palmitoleic acid $(\mathrm{P}<0.01)$, and polyunsaturated $\alpha$-linolenic acid $(\mathrm{P}<0.05)$ in the back fat samples of pigs from the experimental group (tRSM diet).

Nevrkla et al. [18] in the study with pigs of hybrid combination of Large White $\times$ Landrace $\times$ Duroc $\times$ Pietrain pigs, which is very popular in meat production, 
analysed fatty acid composition in the back fat. Their results showed a higher content of C18:3 n-3 (a-linolenic) ( $0.97 \mathrm{~g} .100 \mathrm{~g}^{-1}$ of total fatty acids) and comparable content of C16:1 n-7 (palmitoleic) (2.3 g.100 g $\mathrm{g}^{-1}$ of total fatty acids) in the back fat samples compared to our results.

\section{CONCLUSIONS}

The current analysis showed minor and no significant effects of treated rapeseed meal as an alternative feed resource on growth performance in growing-finishing pigs. The concentrations of serum minerals were not influenced by dietary inclusion of treated rapeseed meal in the growing diet. Both protein feeds (soybean meal and treated rapeseed meal) did not have significant effect on the total proportion of saturated (SFA), monounsaturated (MUFA) and polyunsaturated fatty acids (PUFA) in the back fat of pigs.

\section{ACKNOWLEDGEMENT}

This study was supported by the VEGA project No. 1/ 0402/20 "Effect of additives in nutrition of monogastric animals on production health, production parameters, products quality and environment".

\section{REFERENCES}

1. Agerbirk, N., Olsen, C. E., 2012: Glucosinolate structures in evolution. Phytochemistry, 77, 16-45. DOI: 10.1016/j.phytochem.2012.02.005.

2. AOAC Association of Official Analytical Chemists International, 2001: In Horwitz, W. (Ed.): Official Methods of Analysis, 17th edn., Arlington, USA. AOAC Inc.

3. Benz, J. M., Tokach, M. D., Dritz, S. S., Nelssen, J. L., DeRouchey, J. M., Sulabo, R. C., Goodband, R. D., 2011: Effect of dietary iodine value product on growth performance and carcass fat quality of finishing pigs. J. Anim. Sci., 89, 14191428. DOI: $10.2527 /$ jas.2010-3126.

4. Bell, J. M., 1984: Nutrients and toxicants in rapeseed meal: A review. J. Anim. Sci., 58, 996-1010. DOI: 10.2527/ jas1984.584996x.

5. Blair, R., 2007: Nutrition and Feeding of Organic Pigs. 2nd edn., Cabi Series, CABI, Wallingford, UK, 272 pp.
6. Choi, H. B., Jeong, J. H., Kim, D. H., Lee, Y., Kwon, H., Kim, Y. Y., 2015: Influence of rapeseed meal on growth performance, blood profiles, nutrient digestibility and economic benefit of growing-finishing pigs. Asian-Australasian J. Anim. Sci., 28, 9, 1345-1353. DOI: 10.5713/ajas.14.0802.

7. Čertík, M., Sláviková, L., Masrnová, S., Šajbidor, J., 2006: Enhancement of nutritional value of cereals with $\gamma$-linolenic acid by fungal solid state fermentations. Food Technol. Biotechnol., 44, 75-82.

8. Hanczakowska. E., Swiatkiewicz, M., 2014: Legume seeds and rapeseed press cake as replacers of soybean meal in feed for fattening pigs. Ann. Anim. Sci., 14, 4, 921-934. DOI: 10.2478/aoas-2014-0068.

9. Hansen, J. Ø., Øverland, M., Skrede, A., Anderson, D. M., Collins, S. A., 2020: A meta-analysis of the effects of dietary canola/double low rapeseed meal on growth performance of weanling and growing-finishing pigs. Anim. Feed Sci. Technol., 259, 114302. DOI: 10.1016/j.anifeedsci.2019.114302.

10. King, R. H., Eason, P. E., Kerton, D. K., Dunshea, F. R., 2001: Evaluation of solvent-extracted canola meal for growing pigs and lactating sows. Austral. J. Agric. Res., 52, 10, 1033-1041. DOI: 10.1071/AR01011.

11. Kraft, W., Dürr, M. U., 2001: 30. Reference values. In Hajko and Hajková: Clinical Laboratory Diagnosis in Veterinary Medicine (Slovak/Czech edn.), Bratislava, 365 pp.

12. McDonnell, P., O'Shea, C., Figat, S., O’Doherty, J. V., 2010: Influence of incrementally substituting dietary soya bean meal for rapeseed meal on nutrient digestibility, nitrogen excretion, growth performance and ammonia emissions from growing-finishing pigs. Arch. Anim. Nutr., 64, 5, 412-424. DOI: 10.1080/1745039X.2010.496947.

13. Mejicanos, G., Sanjayan, N., Kim, I. H., Nyachoti, C. M., 2016: Recent advances in canola meal utilization in swine nutrition. J. Anim. Sci. Technol., 58, 7. DOI: 10.1186/s40781016-0085-5.

14. Messerschmidt, U., Eklund, M., Sauer, N., Rist, V. T. S., Rosenfelder, P., Spindler H. K., 2014: Chemical composition and standardized ileal amino acid digestibility in rapeseed meals sourced from German oil mills for growing pigs. Anim. Feed Sci. Technol., 187, 68-76. DOI: 10.1016/j.anifeedsci.2013.10.009.

15. Montagne, L., Loisel, F., Le Naou, T., Gondret, F., Gilbert, H., Le Gall, M., 2014: Difference in short-term responses to a high-fibre diet in pigs divergently selected for residual feed intake. J. Anim. Sci., 92, 1512-1523. DOI: 10.2527/jas.20136623. 
16. National Research Council, 2012: Nutrient Requirements of Swine, 11th rev. edn., National Academies Press, Washington, DC, 400 pp.

17. Nega, T., Woldes, Y., 2018: Review on nutritional limitations and opportunities of using rapeseed meal and other rape seed by-products in animal feeding. J. Nutr. Health Food Eng., 8, 1, 43-48. DOI: 10.15406/jnhfe.2018.08.00254.

18. Nevrkla, P., Kapelański, W., Václavková, E., Hadaš, Z., Cebulska, A., Horký, P., 2017: Meat quality and fatty acid profile of pork and backfat from an indigenous breed and a commercial hybrid of pigs. Ann. Anim. Sci., 17, 4, 1215-1227. DOI: 10.1515/aoas-2017-0014.

19. Okrouhlá, M., Stupka, R., Čítek, J., Lebedová, N., Zadinová, K., 2018: Effect of duration of dietary rapeseed and soybean oil feeding on physical characteristics, fatty acid profile, and oxidative stability of pig backfat. Animals, 8, 11, 193. DOI: 10.3390/ani8110193.

20. Pettigrew, J. E., Soltwedel, K. T., Miguel, J. C., Palacios, M. F., 2008: Fact Sheet-Soybean Use for Swine. Soybean meal information centre. Feedipedia, http://www.soymeal.org/pdf// swineSoybeanUse.pdf 2008.

21. Puls, R, 1994: Mineral Levels in Animal Health-Diagnostic Data, 2nd edn., Sherpa International, Clearbrook, DC, Canada, $356 \mathrm{pp}$.

22. Quiniou, N., Quinsac, A., Crépon, K., Evrard, J., Peyronnet, C., Bourdillon, A., et al., 2012: Effects of feeding $10 \%$ rapeseed meal (Brassica napus) during gestation and lactation over three reproductive cycles on the performance of hyperprolific sows and their litters. Can. J. Anim. Sci., 92, 4, 513-524. DOI: 10.4141/cjas2012-039.

23. Seneviratne, R. W., Young, M. G., Beltranena, E., Goonewardene, L. A., Newkirk, R. W., Zijlstra, R. T., 2010: The nutritional value of expeller-pressed canola meal for grower-finisher pigs. J. Anim. Sci., 88, 6, 2073-2083. DOI: 10.2527/ jas.2009-2437.

24. Siljander-Rasi, H., Valaja, J., Alaviuhkola, T., Rantamäki, P., Tupasela, T., 1996: Replacing soya bean meal with heat-treated, low-glucosinolate rapeseed meal does not affect the performance of growing-finishing pigs. Anim. Feed Sci. Technol., 60, 1-12. DOI: 10.1016/0377-8401(95)00920-5.
25. Skoufos, I., Tzora, A., Giannenas, I., Bonos, E., Papagiannis, N., Tsinas, A., 2016: Dietary inclusion of rapeseed meal as soybean meal substitute on growth performance, gut microbiota, oxidative stability and fatty acid profile in growing-fattening pigs. Asian J. Anim. Vet. Adv., 11, 89-97. DOI: 10.3923/ajava.2016.89.97.

26. Skugor, A., Kjos, N. P., Sundaram, A. Y., Mydland, L. T., Ånestad, R., Tauson, A. H., Øverland, M., 2019: Effects of long-term feeding of rapeseed meal on skeletal muscle transcriptome, production efficiency and meat quality traits in Norwegian Landrace growing-finishing pigs. PLOS ONE, 14, 8, e0220441. DOI: 10.1371/journal.pone.0220441.

27. Smit, M. N., Seneviratne, R. W., Young, M. G., Lanz, G., Zijlstra, R. T., Beltranena, E., 2014: Feeding increasing inclusions of canola meal with distillers dried grains and solubles to growing-finishing barrows and gilts. Anim. Feed. Sci. Technol., 189, 107-116. DOI: 10.1016/j.anifeedsci.2013.12.012.

28. Underwood, E. J., Suttle, N. F., 1999: The Mineral Nutrition of Livestock. 3rd edn., CABI Publishing, United Kingdom, $624 \mathrm{pp}$.

29. Wang, Y., Zhou, J., Wang, G., Cai, S., Zeng, X., Qiao, S., 2018: Advances in low-protein diets for swine. J. Anim. Sci. Biotechnol., 9, 60. DOI: 10.1186/s40104-018-0276-7.

30. Weightman, R., Garland, P., Phelps, E., Clarke, S., Hazzledine, M., Berry, P., 2014: Nutritional value of oilseed rape and its co-products for pig and poultry feed: potential improvements and implications for plant breeders. HGCA (Home Grown Cereals) Res. Rev., 80, 58.

31. Wood, J. D., 1984: Fat deposition and the quality of fat tissue in meat animals. In Wiseman, J. (Ed.): Fats in Animal Nutrition, 1st edn., Butterworths, London, UK, 407-435.

32. Yun, H. M., Lei, X. J., Lee, S. I., Kim, I. H., 2018: Rapeseed meal and canola meal can partially replace soybean meal as a protein source in finishing pigs. J. Appl. Anim. Res., 46, 1, 195-199. DOI: 10.1080/09712119.2017.1284076.

Received August 27, 2020

Accepted October 16, 2020 